\title{
Chapter 6: Miłosz and Multi-Racial Society in the United States
}

\section{Mitosz and Native Americans}

Reading translations of novels about American Indians was a component of the upbringing of boys among the Polish intelligentsia in the 19th century and the first half of the 20th century. When the country was partitioned under Russian, Prussian and Austrian rule, these novels were often read in an Aesopian way, where the red and white characters corresponded allegorically to the figures of patriots and invaders. Only after returning to Europe in 1950, when Miłosz reassessed his past experience, he reminisced on the books read in childhood in his work on the novels The Issa Valley and Native Realm. In The Issa Valley, the narrator says the following about Tomasz:

Pretending he was in a dugout, he stood on the footbridge and took potshots at the ducks. This once led to an investigation when one of the ducks was found dead in the middle of the pond and he refused to take the blame. Since the Indians were known for hunting fish with a bow and arrow, he was constantly on the lookout for fish along the river shoals (so as not to lose any arrows), but they always got away in time (The Issa Valley, 64).

In the description of a kayaking trip to Paris, we read:

\footnotetext{
Every bend in the river concealed a secret which, when disclosed, took our breath away. If anywhere, it was here we could have said that we had penetrated into an enchanted land. From the steep slopes, branches hung out over the green water, making grottoes which were surely homes for nymphs. In those branches, Delaware warriors from the novels of Fenimore Cooper could have been crouching (Native Realm, 154).
}

Inclusion of his own biography in a literary framework is one of Miłosz’s main narrative strategies not only in The Issa Valley and Native Realm. In the fragments quoted above, his reading experience and his biographical experience, and his distant and recent past, are integrated. The act of integration, recurring in Miłosz's poetry and prose of the 1950s, is a peculiar effort of self-reparation, necessary to overcome the trauma of the war, the Hegelian bite, and the post-war fury of the American years. Why is this important? In order to show what the poet initially thought about history and contemporaneity, it is worth looking at some point of access in a later period of his work. Since already in the 1950s he showed a post-colonial sensitivity in the chapter on the extermination of the Baltic peoples in The Captive Mind, while in Native Realm he called Lithuanians the "Redskins of Europe," it is worth asking where and under what influence this outlook was born. There are many indications that this was a path leading through books, mediated by the written word rather than a reflection of important meetings, conversations, or events: Miłosz's stay in the United States shed new light on his youthful readings. It was there that he discovered the colonial 
character of the books read in childhood, which allowed him to reinterpret PolishLithuanian relations as colonial relations on returning to Europe.

In the 1940s, Miłosz travelled extensively on the East Coast, and the routes of his trips can be recreated with relative ease. He visited industrial and academic cities on business, and with his family he liked to go to the ocean, to the woods, and on river cruises. He did not look for traces of reality behind novels about American settlers and Natives. At that time, Miłosz used a strongly polarized and very traditional thought scheme: American nature was nature par excellence, observed through Manichean and Darwinian lenses - then the last part of his A Treatise on Poetry, entitled "Nature," was written - while history was the domain of people, but, most importantly, mainly of the residents of metropolises. In the countryside, there was no flow of historical time, only the wheel of the seasons revolved endlessly there biological life, whose changeability was simulated in the irregular rhythm of village dances and local armed robberies. History was made in big cities, political offices, newspaper editorial rooms and stock exchange offices, even though, as early as 1946, Miłosz wrote the following words:

Surprising things in the United States can be seen only in the provinces. New York's monumental ugliness is in fact only an escalation of the characteristics of any big city. A small town in the woods is uniquely American, and for good reason have American sociologists devoted many monographs to it. The fate of the world depends to a large extent on the American small town, which, combined with other small towns, makes up the character of one of the two great powers that rule world politics. ${ }^{671}$

Familiarity with Miłosz's journalism and correspondence of that period allows us to assess how deeply ironic this statement was - the idea of the provincialism of the American Empire recurs more than once in his works written at the time. Immediately after his arrival in the United States, he put an equals sign between history, politics, and economics on the macro scale. He mapped out the world on the center-andprovinces model, in which the former was the strong center of influence, while the provinces were mainly the territory for absorption. His thinking was burdened by a totalitarian influence, tinged with the Manichean and Marxist image of a constant struggle of the strong with the strong. In the 1940s, the history hidden in the names of American rivers, forests, geographical landscapes, mountain ranges and peaks evaded the recent lover of Belarusian folklore, and translator of Baltic poems by Kazys Boruta. The history of Native America from the times of the conquest, etched in its onomastics, remained invisible to him for a long time. Even there, however, he was also tired of the occupation dilemma related to the tasks of art and duties of the poet. This situation is best illustrated by the poem "Na śpiew ptaka nad brzegami Potomaku” [On a Bird's Song Heard on the Banks of the Potomac], written in 1947. On

671 Miłosz, Czesław: “Massachusetts”, op. cit., p. 6. 
the one hand, it is a classic poem-lament on the river of time, inscribed in the literary tradition of mourning one's fate:

Kiedy zakwita magnoliowe drzewo I park zielonym zmąca się obłokiem, Słyszę twój śpiew nad brzegiem Potomaku W uśpione płatkiem wiśniowym wieczory. Wybacz mi, proszę, brak tego wzruszenia, Które prowadzi przemocą z powrotem W miejsca i wiosny dawno zapomniane, Aby maluczkich uwodził poeta Patriotycznym sentymentem, serce Cisnął stęsknione i farbując łzy, Mieszał dzieciństwo, młodość, okolice. Mnie to niemiłe.

Wiersze 2, p. 32
When the magnolia tree comes into blossom, And the park swirls with billowing clouds of green, I hear your song on the banks of the Potomac At dusks, lulled to sleep by pink cherry petals. Forgive me, please, this lack of emotion, Which leads the mind forcibly back To places and springs long forgotten, So that the poet might seduce the lowly With patriotic sentiment, hurling their hearts Forth and tingeing their tears, Mixing up childhood, youth, and surroundings. I find it disagreeable.

The rhetorical figure of apóphansis, an apparent declaration of omitting some issues, is an introduction to Miłosz's reminiscences on his childhood at the Sigismund Augustus Gymnasium in Wilno, his youth, stylized as philomatic, in the Academic Vagrants' Club, mass murders of Jewish, Polish, Roma and Russian people committed in the Ponary forest in 1941-1944 by the SS assisted by volunteer units of Lithuanian police. The author returns to his rhetorical reservations in these words:

Już nie pamiętam. Ptaku, wdzięczny ptaku, Ty, który dzisiaj śpiewasz mi to samo, Co słyszał tutaj indyjski myśliwy Stojący z łukiem na ścieżce jeleni, Cóż możesz wiedzieć o zmianie pokoleń I o następstwie form w ciągu jednego Ludzkiego życia? Tamte moje ślady Zatarł nie tylko pęd zim i jesieni. Ja byłem świadkiem nieszczęść, wiem, co znaczy Życie oszukać kolorem pamiątek. Radośnie słucham twoich ślicznych nut Na wielkiej, wiosną odnowionej ziemi. Mój dom sekunda: w niej świata początek. Śpiewaj! Na perłę popielatych wód Syp rosę pieśni z brzegów Potomaku! Wiersze 2, pp. 32-33
I no longer remember. O bird, graceful bird,

You, who are singing the same tune to me, That an Indian hunter heard here Standing with his bow on the deer path, What could you know about changing generations,

On the succession of forms within one

Human life? Those traces I left, Effaced not only by the rush of winters and falls.

I was a witness to misfortune, I know what it means

To cheat life with the color of keepsakes. I listen joyfully to your lovely notes On this great Earth, renewed by spring. My home - a second: in it the world's beginning.

Sing! Over the pearl of the ash-colored waters

Spread your song like dewdrops from the banks of the Potomac! 
The interplay of meanings in the poem results from the use of two identities: the song of the bird over the Potomac sounds like the singing of birds heard by the poet in his youth in his home country, and it becomes - in as in Proust - a stimulus for remembrance, which the poet resists, but at the same time the birdsong sounds the same as it did centuries ago, before the colonization of America, to an Indian hunter - in this way the poet introduces the idea of slow evolution, almost imperceptible in comparison with the pace of history, especially within the framework of a single human life. Evoking the image of the Indian hunter not only highlights the drama of a human whose history, wherever and whenever it takes place, is always indifferent to nature. It is also a reflection on history, where a single lifetime is a mere second. This thought becomes the source of both pessimism and, paradoxically, of consolation. Even though this is not clear in the foreground of the poem, its protagonist is in favor of the second possibility: he wants to listen to the song of the bird. But - as Jerzy Jarzębski comments,

- nothing comes free in the world of the poet: to enjoy the trills of a bird, which are always the same, because they reflect the eternity of nature (relative, yes, relative, but let us not be too particular) - one must, even for a moment, erase the memory of the world of human history, based on constant change, and on destruction of keepsakes. ${ }^{672}$

So why listen to the song of the bird? Would it be a sign of fidelity to oneself, one's youthful poetic imagination, in which birds had an important symbolic place, or a sign of faith in the spiritual order, of which the bird is sometimes a delegate - as we know, in many religious systems and traditions birds were symbols of the spirit, spirituality, a higher reality. Is it a gesture of embracing the poetic tradition in which invoking birds started the most intimate soliloquies, as in John Keats' "Ode to a Nightingale”? Is this a sign of interest in the spirituality of Native Americans, where the Supreme Being often merged with the mythical personification of lightning and thunder, which was a great bird? There is no need for a single answer to these questions. ${ }^{673}$ Something else is important here: in the poem, the river does not become an impulse for reminiscences on the Native American people living in this area, nor on the history of the Civil War, in which the Union Army of the Potomac fought a number of victorious battles. Only

672 Jarzębski, Jerzy: “Obrazy Ameryki w Świetle dziennym Miłosza” [Images of America in Miłosz’s Daylight], op. cit., p. 4.

673 The situation of this poem, on many transformations, will become the model situation of the poet, of which Seamus Heaney wrote as follows: "In other words, these two figures which constantly recur in Miłosz's poetry - the boy in the power of dreams on the bank of a river, and the grown man held captive by necessity - represent the destiny of the poet who lives between two places: his place on Earth, and in exile, in his art.” In idem: “Czesław Miłosz i poezja światowa.” [Czesław Miłosz and the World Poetry]. Translated by Renata Gorczyńska, Zeszyty Literackie 1999, issue 2, p. 53. 
in the series $\dot{Z} y$ cie $w$ USA [Life in the USA] did Miłosz recall a trip to the river during his visit to the state of Virginia.

There is nothing to suggest that the diplomat had the opportunity to meet the Native Americans of the East Coast. Decimated by the wars, they were pushed into the territories of the central states. ${ }^{674}$ His correspondence and articles do not even mention a desire to meet them. It is in his wife's letter to Andrzejewski, dated 25 July 1946, where we find the following remark:

The ride on the Hudson River, by which we often camped with a friendly tribe of Indians during the steamy nights of the adventurous youth of our teenage years, was intoxicating. At the same time, it brought disappointment. Is there really nothing left of it? Well, No. Brazen white men, who think that they deserve everything, came over here to stay (Zaraz po wojnie, 42-43). ${ }^{675}$

Neither did the holiday in Rehoboth Beach inspire Miłosz to look for traces the culture of the Delaware tribe. ${ }^{676}$ In his works in written those years there is not a single description of a Native American, which should be explained not so much by a lack of interest, but first of all by the situation of the marginalized Native Americans, rarely living in cities, and secondly, by the situation of the diplomat himself, absorbed by the affairs of Europe, seen in relation to white America. In Poland, the history of Native Americans also did not concern Polish historians and columnists at the time - the exception here would be essays by Arkady Fiedler about Mexican Indians and Cortés, which the poet, collaborating with Odrodzenie, certainly read. ${ }^{677}$ He was also undoubtedly familiar with Aimé Cesaire's speech on the colonial policy of the West delivered at the World Congress of Intellectuals for Peace, in Wroclaw, Poland. ${ }^{678}$ Bogdan Żyranik wrote the following in his commentary to his own translation of "The

674 The history of Native Americans is treated exhaustively by Champagne, Duane in the book Native America. Portrait of the Peoples. Foreword by Dennis Banks, Detroit: Visible Ink Press, 1994.

675 A counterpart of this remark in Miłosz's articles are the words: "The banks of the Hudson River, whose estuary was the site where industrious colonizers founded New Amsterdam, later known as New York, are among some of the most beautiful places in the world. Their wild, rocky and wooded landscape makes one imagine the moment when the first boat of white settlers moved carefully upstream, and from above, from caves hidden in the vegetation they were followed by gazes of Indians.” In Miłosz, Czesław: "Notatnik nowojorski” [The New York Notebook], Przekrój 1946, issue 70, p. 11.

676 The fate of this tribe is discussed in Weslager, Clinton A.: The Delaware Indian Westward Migration, Wallingford, Pennsylvania: The Middle Atlantic Press, 1978.

677 See Fiedler, Arkady: "Chwała indiańskiej przeszłości” [Glory to the Indian Past], Odrodzenie 1949, issue 21; idem: “Cortez, el destructor,” Odrodzenie 1949, issue 24, p. 2.

678 Cesaire, Aime: "Sprawa ludów kolorowych” [The Issue of Colored Peoples], Kuźnica 1948, issue 2, p. 6. In the 1950s Miłosz reviewed the book by Bhattacharya, Bhabani: So many hungers, London: V. Gollancz, 1947, covering the famine in Bengal, Ghandi's movement and India's aspirations for independence. The manuscript of this review is kept at the Beinecke Library, Box 127, Folder 2036. 
Song of Hiawatha:" "When the Blacks are still treated today in the United States with a multitude of racial superstitions and phobias, the Indians are not touched by these superstitions." 679

Although Miłosz's knowledge of Native Americans was not mediated by reading, it is worth mentioning the titles of the books that led him to their tracks. The most important historical book of those years was Edward Gibbon's The History of the Decline and Fall of the Roman Empire; ${ }^{680}$ the Native American context was suggested by In the American Grain by William Carlos Williams ${ }^{681}$ and The Conspiracy of Pontiac by Francis Parkman. ${ }^{682}$ From the volume of essays by Williams Miłosz translated two excerpts about the conquest of South America and the fall of the Aztecs and gave them his own titles: "Wyspy ziemskiego raju albo gospodarka folwarczna w Indiach Zachodnich w XVI w., czyli Ponce de Leon” [The Islands of Earthly Paradise, or Manor Economy in the West Indies in the 16th century, i.e. Ponce de Leon] and "Zniszczenie miasta Tenochtitlan czyli koniec państwa Azteków, albo biada zwyciężonym” [The Destruction of Tenochtitlan, that is the End of the Aztec state, or Woe to the Defeated]. From Parkman's work he chose to translate a dialogue from an anonymous satirical play Ponteach: or the Savages of America from 1766. These translations were published in a joint collection under the title "Małe wypisy historyczne albo czytanki na lato dla miłośników dawnych dobrych czasów” [A Small Historical Reader or Summer Readings for Lovers of the Good Old Days] ${ }^{683}$ - among them there was also a short fragment of Gibbon's Decline, entitled “Błogosławiony Marcellus czyli zapał

679 Longfellow, Henry Wadsworth: "Pieśń o Hajawacie" [The Song of Hiawatha]. Translation and commentary by Bogdan Żyranik, Twórczość 1946, issue 7-8, pp. 78-79.

680 Miłosz read The History of the Decline and Fall of the Roman Empire in the original. How important this book was for him is attested by the fact that he returned to its Polish translation at the end of his life, and also by the essay devoted to Gibbon "Upadek Cesarstwa Rzymskiego czyli coś dla zwolenników śródziemnomorskiego mitu" [The Fall of the Roman Empire or Something for the Supporters of the Mediterranean Myth], Tygodnik Powszechny 2002, issue 48, reprinted in the volume O podróżach w czasie [On Time Travel]. Selection, preparation and introduction by Joanna Gromek, Krakow, 2004, pp. 46-59.

681 The first edition of Williams' book was published in 1925, whereas Miłosz most likely used the edition published by New Directions in Norfolk, Connecticut from 1940. As we know, Macdonald was the author of the book Against the American Grain, New York: Random House, 1962. Nonetheless, Miłosz did not mention anywhere that Williams' collection of essays was ever a subject of their conversations.

682 Miłosz probably used the edition History of the Conspiracy of Pontiac and the War of the North American Tribes against the English Colonies after the Conquest of Canada. With an introduction by Joseph Schafer, New York: Macmillan, 1929. During his diplomatic service, another important book came out, namely McNickle, D’Arcy: They Came Here First: The Epic of the American Indian, Philadelphia: J. B. Lippincott, 1949 - Miłosz's writings do not reveal whether or not he read it.

683 "Małe wypisy historyczne albo czytanki na lato dla miłośników dawnych dobrych czasów" [A Small Historical Reader or Summer Readings for Lovers of the Good Old Days]. Selected and translated by Czesław Miłosz, Nowa Kultura 1950, issue 20, p. 2. 
chrześcijański w IV wieku po Chr. albo konserwatywni wieśniacy” [Blessed Marcellus or Christian Zeal in the Fourth Century AD, or Conservative Villagers].

The translations from Williams and Parkman were reprinted in Kontynenty [Continents] and provided with new comments. In the case of Williams, the poet argued that "This is the title of one of the most beautiful books on the history of the American continent" (Kontynenty, 149). He wrote the following about the dialogue from the English satirical play: "I have translated these fragments, because the dialogue in verse, entirely realistic, and even trivial, seemed to me to be something difficult to achieve in the Polish language, and tempting” (Kontynenty, 155). Miłosz never republished his fragments from In the American Grain. Very clear is the act which, over time, Miłosz the translator repeated - a gradual and consistent decontextualization of the old translation. While the poet Polonized certain texts with a clear intention of using them as a substitute voice in the realities of the Stalinization of life in Poland, after more than fifty years he focused on their strictly cultural and literary values. Only to Kroński did he reveal his original intentions:

I am already finishing Act II of Othello, I have also prepared a small historical reader, from Gibbon, and from various Americans, including verse, e.g. fragments from 18th century plays about the martyrdom of Indians, the whole thing is quite venomous, I sent it to Nowa Kultura, they might just print it (Zaraz po wojnie, 380).

This example shows how Miłosz's understanding of the utility principle evolved: translating stories about the colonization of America, the poet understood it narrowly and ad hoc, and when the current purpose disappeared, he incorporated the old translations into the realm of poetry on the rights assigned to other works. In the 1940s Miłosz used Native American history as an emblem of the permanent laws of history, he retold stories of the bloody conquest of America not as further arguments against the Western empire, but as evidence of the repetition of history. He made them his 'Aesopian voice.'

Interesting and well thought-out is the strategy chosen by the editor of "Małe wypisy historyczne." The syntax of the titles given to the juxtaposed excerpts imitates the models of Polish textbooks and didactic literature of the 18th century. What is more, according to the Enlightenment rule of docere et delectare, each of them, not only thanks to open stylization, contains a dose of humor, achieved through imitation of moralistic clichés. The title puts the translation in Miłosz's own quotation marks - an official strategy of reading is thus imposed on the reader. As the editor of the collection, Miłosz reveals himself here in the role of a mocking hunter of absurdity, an exposer of past stupidity and cruelty. He can go far, since the stigmatized situations concern the history of Christianization, exploitation and extermination of Native Americans. As the recent author of "Campo dei Fiori," "A Song on the End of the World," and the "Song on Porcelain," Miłosz can afford such an openly ironic gesture. Once again, he benefits from the antagonization of form and content, breaking 
the principle of decorum, nomen omen, in an enlightened way. Putting everything in double quotes, in the stories of the conquest of America Miłosz smuggles an exemplum, teaching about the foreseeable effects of various actions against the occupiers. The story of chief Montezuma, who first surrendered to Cortés without a fight and then could not prevent the uprising that broke out after his imprisonment, seems particularly valuable here:

In response to screams from the outside, Montezuma, a prisoner, appeared on the walls of the besieged fortress and began to call on his people to stop the attacks. It was then that a stone thrown from the crowd struck him in the head and killed him. Only their horses and their military formation saved the Christians in their memorable retreat on the great dyke. Fighting madly to break through the enemy's ranks with the rest of their forces, and to keep the prisoners and the treasures at the same time, Cortes lost everything. Montezuma's children, the gold, everything was lost on this crowded route through the lake, with the Spaniards retreating step by step from the swarms of Indians throwing themselves against them. They fled. Several months later they returned and continued their work of destruction, this time with premeditated cold calculation. Tenochtitlan was surrounded, the flow of water was cut off, and the strengthened Spanish forces started to slowly break through, and after several weeks of desperate effort they reached their goal. ${ }^{684}$

Miłosz is not interested here in the Native Americans as Native Americans, not least because the Native American question does not appear to him as clearly as does the issue of African Americans at the time. The poet sees this more broadly, and perhaps the best illustration of this is the fragment of In the American Grain he selected for translation:

They took them in droves, forced them to labor. It was impossible to them - not having been born to baptism. How maddening it is to the spirit to hear: - Bands of them went into the forests, their forests, and hanged themselves to the trees. What else? Islands - paradise. Surrounded by seas. On all sides "heavenly man" bent on murder. Self-privilege. Two women and one man on a raft had gotten one hundred and fifty miles out to sea - such seamen were they - then luck again went against the Indian. Captured and back to slavery. Caravels crept along the shore by night. Next morning when women and children came down to the shore to fish - fine figures, straight black hair, high cheekbones, a language - they caught them, made them walk in bands, cut them down if they fainted, slashed off breasts, arms - women, children... ${ }^{685}$

Miłosz had already seen this, and he read about it - in Conrad. Already in "Notatnik amerykański” [The American Notebook] from 1948 he wrote:

684 Miłosz, Czesław: "Zniszczenie miasta Tenochtitlan czyli koniec państwa Azteków albo biada zwyciężonym" [Destruction of the City of Tenochtitlan, that is the End of the Aztec State or Woe to the Defeated], op. cit., p. 4.

685 Miłosz, Czesław: "Wyspy ziemskiego raju albo gospodarka folwarczna w Indiach Zachodnich w XVI w. czyli Ponce de Leon” [The Islands of Earthly Paradise, or Manor Economy in the West Indies in the 16th century, i.e. Ponce de Leon], op. cit., p. 4. 
To civilization, man officially begins from the belt upwards, the natural man, unfortunately, stinks. This agreement, as if it were a theatrical convention, also extends to man's urges, their limit which is cruelty and brutality, is bypassed.

Of course, the shell is fragile, and the whole of civilization is fragile.

The sight that shook me the most me was the disintegration of this shell in Warsaw, in September 1939. Afterwards one would see all sorts of things. But those faces of the tired, sweaty women, their makeup and lipstick dripping in streaks at the mouth - that was the symbolic beginning. Yes, the civilized Brussels of the marble societés anonymes, where Joseph Conrad signed his contract to depart for the Congo, was an illusion. What was real was the Congo (Kontynenty, 38-39).

The poet did not need any additional evidence in this case. He prepared his "Małe wypisy historyczne" after the publication of Traktat moralny [Treatise on Morals], after the Szczecin meeting of the Union of Polish Writers and his visit to Poland in the summer of 1949. Thus, he reduced the particulars to the common denominator of cruelty, and if so, this would be a significant act of expanding his historiosophic consciousness, which would direct him in The Captive Mind toward a search for a more general model in spatially and temporally distant events, problems and historical processes.

This does not mean that Miłosz was not interested in the ethnic and racial diversity of American society. It is not known whether among his many readings was John Collier's seminal work The Indians of the Americas, published in New York in $1947 .{ }^{686}$ With Wanda Telakowska, he travelled to Santa Fé, the largest Native American

686 The book by Collier, John: The Indians of the Americas, New York: Mentor Books, 1947 covered the prehistory of Native Americans, including the Empires of the Incas and Aztecs, the history of the Spanish conquest of South America, management of the colonies by the Spanish Crown and the Catholic Church until the Napoleonic era, the wars fought in the Americas during the Napoleonic era, the Mexican Revolution, the history of Native Americans in the United States considering its territorial division, the history of Native Americans during the Mexican Revolution, and the realities of life of Native Americans until the end of the 19th century. Collier, a well-known advocate of Native Americans, presented the cultural history and extermination of Native Americans from their point of view. As early as the 1920s, he became interested in Native American issues. He strove to improve their situation during the Great Depression, and to achieve broader changes in the policies directed toward them. He sharply criticized the activities of the Bureau of Indian Affairs. During Franklin D. Roosevelt's presidency, he was invited to cooperate with the administration as Commissioner of Indian Affairs. At that time, he established the Indian division of the Civilian Conservation Corps which oversaw material issues, the situation in reservations, and renewal of the natural environment destroyed by white people, so that Native Americans could again engage in their own agriculture. He was instrumental in the passage of the Indian Reorganization Act in 1934, which was then considered part of the New Deal policy. He rejected the policies of the time which imposed forced assimilation and Americanization of Native Americans following the rules of the white immigrants. On finishing his work with the federal government, he became the director of the National Indian Institute. John Collier settled in California in 1919. It was there that he first came into contact with the art of the Pueblo Indians of Taos, and then led the thriving development of the town of Santa Fé, which became 
art center in New Mexico at the time, created also thanks to the efforts of Collier, a defender of Native Americans and connoisseur of their art, fascinated by the Pueblo culture. In 1948, the first lady of Polish design had an exhibition of Polish folk art in the USA, and the secretary of the Embassy organized help for her and accompanied her on her journeys. In May 1948, Santa Fé became their most distant - and not accidental - destination, where Telakowska could seek inspiration for her book. ${ }^{67}$ Unfortunately, no photographs have survived from this journey. The poet wanted to reach Miller, who lived in Big Sur, California. He recorded his walk around the town in "Notatnik amerykański" [The American Notebook] rewritten and included in the Kontynenty - the entry devoted to Santa Fé remained in the new version without any changes. Miłosz, however, had doubts as to whether it was worth developing this topic:

I started to write about Santa Fé and the Taos valley, but I lost my spirit. The question is why. One's aversion to the thing one writes usually proves that something is wrong. Either the subject or the way of writing. The subject - in itself, quite rich. Not many people from Poland arrive in the depths of the American continent, on the border of the United States and Mexico (Kontynenty, 42). ${ }^{688}$

Since few readers in Poland ever found themselves deep in America, few might have been interested in these issues, and in what Miłosz might have written about them. The question is whether the subject he took up was attractive, while at a deeper level, it concerns common cognitive practices, i.e. whether people would rather read about what they did not yet know about or would prefer to deepen their knowledge of what they already know. The author did give an account of the history of the conquest of those lands, the Spanish rule and Native American wars with the colonizers, described the historic palace of the governors, wrote several lines about the climate and colors of the landscape, and looked for possible points of reference: he compared the discovery of Native American art to the fashion for the Polish highlander art, and looked at nature through the prism of civilization and literature. In the end he surrendered:

Here, in the desert of New Mexico, a dozen or so miles from Santa Fé, in an inhuman landscape, the atomic bomb was born. In the Taos valley, which you enter through a gorge of ashen volcanic rocks - suddenly a gentle green space opens up at the foot of the snowy mountains - English writer D. H. Lawrence lived and died here. He considered this to be the most beautiful place he knew, and since he condemned modern civilization as devoid of sensual fullness in all his books,

a Native American art center after the war. See Santa Fe. History of an Ancient City. Edited by David Grant Noble, Santa Fe: School for Advanced Research Press, 2008; Collier, John: From Every Zenith: A Memoir, and Some Essays on Life and Thought, Denver: Sage Books, 1963.

687 See Telakowska, Wanda: Twórczość ludowa w nowym wzornictwie [Folk Art in New Design], Warsaw, 1954.

688 The visit in Taos did not inspire Miłosz to reflect on the work of Robinson Jeffers at the time. 
he was fascinated by the original rituals of the local Indians. The object of these burnt mountains of New Mexico would have provided an opportunity for writing. But the object must be attached to some passion of ours; it must become a personal matter for us. New Mexico, even though I was there, is for me like a country seen in the cinema (Kontynenty, 43).

There are several secrets hidden in this remark. Miłosz marks the contrast between seeing something directly and seeing the same on screen but does not explain what the difference means to him. The key seems to be a matter of "passion," a "personal matter," without which what you see in person looks as if on screen. Many times, the poet complained that America of the 1940s was not sufficiently real for him, but is this what the cinematographic metaphor seems to suggest? Or is it about the exotic nature of the landscape, which, although seen in person, is so fundamentally different from what Miłosz was used to that it seemed to be the background of a film from some distant, foreign land? And what kind of film did he have in mind: a feature film, documentary, or newsreel? The analogy with cinema probably does not concern the situation of mediation - after all, the poet himself searches for the possibility of taming the unknown in historical parallels, and in references to civilization. Perhaps, then, the point is the sense of unreality, stopping of the development of the Pueblo culture in a phase which the contemporary resident of a metropolis cannot feel as his own. The poet goes on to explain this further:

As for the way of writing, perhaps dyed-in-the-wool prose writers feel the pleasure of meticulously repeating the details of reality on paper. At any rate, there is probably such a variety of prose writers. If writing about New Mexico started to make me weary, it is probably because I am not attracted to making an inventory of reality, but rather to the tensions in it (Kontynenty, 43).

One such dramatic tension seems to be found in a religious ritual in which young Native Americans participate: the poet finds it incredible that it is possible to return to traditional ritual after the experiences of war in Europe.

Miłosz knew that in the last war young Native Americans were soldiers valued for their exceptional manual skills - here he observed that the Native American community returned to the old practices, as if their history had been following a different track. Dry, dialectic reason shifted their indigenous practices into the sphere of theatrical folklore.

The reader of Conrad and Gibbon exposed analogies between the practices of conquistadors, armed missionaries and Marxists. The intuitions written on the first pages of Native Realm were born there and then, although it is not certain how early Miłosz was accompanied by the thought formulated precisely in this form.

In "Notatnik amerykański" [The American Notebook] written in America, Miłosz reflects on the commercialization of Native American art, and on the destructive influence of the market on its originality: 
Now this Indian art (necklaces, fabrics, ceramics) is ending because it is in the hands of shopkeepers, for whom Indians work as cottage-industry workers. It is clear that the orders follow the tastes of the customers, which are terrible. This is how the last center of handicraft and folk industry in America is dying out (Kontynenty, 44-45).

The poet makes observations on the twilight of Native American art at a time when Americans consider the restoration of Santa Fé to its former splendor a success...

The account of a visit to Taos contained in "Notatnik amerykański" reveals the ambivalence with which Miłosz approached Native Americans in the 1940s. For a long time Miłosz had been unable to define his attitude towards Native American culture that was spread - as his impression would indicate - between the open-air museum and the hieroglyph. The metaphors he used - of a theatre spectator and moviegoer - emphasize the difficulty of his situation. It would seem that we were at the center of Miłosz's dilemmas if we were to stop at his published accounts from his journey to California, edited and included in "Notatnik amerykański” [The American Notebook]. Meanwhile, the freshest and most complete testimony to the poet's stay in Santa Fé is the extensive, unfinished composition "W dolinie Taos" [In the Taos Valley], ${ }^{69}$ preserved only as a manuscript. It consists of nine parts of unequal length, separated with asterisks. It takes the form of a journal from a journey, understood more as a literary essay than a documentary account in the strict sense of the word; descriptions of the places seen and customs learned are usually accompanied by more general reflections of a different character. It preserves the chronological order of his visit to California at least partially: it begins with a description of the flight and landing in Santa Fé, and ends with a reflection on folk art, and it is interrupted in the first sentence of the description of the village of Tesuki. The narrator acts in it as a documentary filmmaker and camera operator: from sketching out the historical background and landscape of the land, he moves on to observations on the town, a village, a street, and finally to individual scenes and eye-catching details. He describes the New Mexico landscape from the perspective of an airplane passenger - his sight is attracted by clouds, compared to clouds in the country of his childhood. It ends with a brief description of the tiny airport opposite the vastness of the surrounding empty space. Miłosz then tells the story of the town of Santa Fé from the time of the first settlers until it was taken over by the United States. He outlines the origin, evolution, conditions of development and achievements of the local civilization from the great ancient migration of peoples. His knowledge of history is combined with archaeological knowledge, which shows how well he had prepared for his first visit to the southern border of the USA. His camera lens narrows down the angle in the following remarks that describe Santa Fé itself: its landscape, location, climate, architecture, and its racially, ethnically and linguistically diverse population. The antithesis to this description is a remark about the construction of the atomic

689 Miłosz, Czesław: “W dolinie Taos” [In the Taos Valley], Beinecke Library, Box 118, Folder 1777. 
bomb - this reflection Miłosz will rewrite in "Notatnik amerykański" [The American Notebook]. From Santa Fé, he moves to Taos, the way to which he will describe later in the essay. While driving to Taos, the driver directs the passengers' attention to the roadside information boards with facts about the history of the region - Miłosz juxtaposes the attitude of Americans and Poles to their own history, accusing the latter of particular neglect. He also recalls here the figure of Lawrence, an inhabitant and lover of the Taos Valley: he is an ethnographer who devoted many pages to the culture and customs of Native Americans. Only now does Miłosz reflect on the situation of the Native Americans, discussing their close past, their great military service in the Second World War, and their present economic and legal situation, including lack of voting rights. For the poet who often thinks of alienation as a sign of his contemporaneity, their attachment to their village and roots is very meaningful. However, he sadly observes how former soldiers, and not rarely Japanese prisoners become shop assistants selling commercialized folklore products for tourists. This extensive observation would not be repeated by the poet anywhere else, just as he would not publish anywhere else his description of the impressions from a Native American procession on the harvest festival. In "Notatnik amerykański," Miłosz mentioned this event as an example of the fusion of paganism and Christianity, but only in this unpublished sketch he expressed his enchantment with the exoticism and magic of this ritual.

Both the point of departure and the point of access are different in both accounts. The diary is governed by immediate impressions. In the "Notatnik" [The Notebook] in keeping with the author's own declaration - the impressions have been subjected to the test of time and selection, and included in the whole as functional elements, leading to certain generalizations assumed a priori. The ecstatic viewer from the diary transforms into a calm artisan, who achieves his goals playing the game of disclosure and concealment. Why did Miłosz not publish the colorful story about the Taos Valley?

It does not seem that he doubted its intellectual and literary merits. Rather than that, the strategy of assuming masks and roles, of key importance for Miłosz, was revealed here. In other words, he carefully managed his capital of knowledge, awareness, and experience. One can distinguish in his writing at the time the roles he assumed, and discern the levels of information he shared, and estimate how much of the knowledge he assimilated at that time he kept for himself for a long time. The fate of the unpublished composition "W dolinie Taos" [In the Taos Valley] encourages us to consider how long Miłosz needed to maintain his garden of learning before he would open the gate to it for others. Would his Taos experiences not return transformed in The Issa Valley, and in Native Realm? They did return, of course, but only at the moment Miłosz chose himself, and in accordance with his understanding of the principle of mimesis, where the condition of imitation is purifying his gaze of passions and desires. Similarly, in his introduction to the anthology Kultura masowa [Mass Culture], the remarks from the diary on folk art return - perhaps inspired by conversations with Telakowska and by reading politics. 
The accounts from the trip to Santa Fé from the diary and "Notatnik" are, on a micro-scale, the limits of the process that proceeded from getting to know America to a reassessment of his initial American experience. The example of the change of perspective on Native Americans is quite instructive here - the poet published some of his old opinions in the new approach, but also - in accordance with his sense of hierarchy - he kept secret those of them which were supposed to mature and become the basis for deeper, more important and more general diagnoses. The ambivalence of "Notatnik" [The Notebook] is one thing. The ethnographic, anthropological, and spiritual fascination with Native Americans is another. This fascination, even if concealed, determines the continuity of imagination for the author of Traktat moralny and The Issa Valley. Already in the 1940s, the poet unveils the secret. In the Native American, what attracts him, as he betrays in his correspondence, is the inner man, the homo religiosus. He writes to Matuszewski:

Why are the barefooted Aztecs capable of absorbing the paintings of Diego Rivera or Siquerios? Why is an average French film too difficult for an average American audience? Why was the great poetry and great music of Negro spirituals created by Negroes, slaves and illiterate people? Because in people there is death, atrophy, downfall, inertia, sentimentalism - and there is life, flourishing, power, grandeur - and whoever thinks and uses the effort of will, is bad if he plays for death, and not for life (Zaraz po wojnie, 429).

\section{Mitosz and Black Americans}

In the literary returns to his birthplace, Miłosz refers to his childhood books and, as he reminisces in The Issa Valley, beside the stories about Indians,

He had more fun with the travel books. Negroes, armed with bows and arrows, were shown standing naked in reed boats, or towing a hippopotamus familiar to him from his natural-history book. He often wondered whether their bodies were really striped, or just painted, and dreamed of accompanying them on a long voyage to distant waters, and, among papyrus plants standing taller than a man, of building a village inaccessible to outsiders (The Issa Valley, 63).

It is not known whether these books included the famous novel Uncle Tom's Cabin by Harriet Beecher Stowe. ${ }^{690}$ Miłosz's meeting with African Americans, getting to know their situation and culture created in America was different than his encounter with Native Americans. Entering the New World, Miłosz already knew the history of American slavery, and had some idea of the living conditions of black people. Unlike Native Americans, African Americans were also residents of New York and

690 The novel titled Chata wuja Toma. Opowiadania dla młodzieży z czasów niewoli murzyńskiej [Uncle Tom's Cabin. Stories for Youth from the Times of Negro Slavery] was published for the first time in Lwów in 1912 by the Publishing House Kultura i Sztuka, translated into Polish by Józef Łomnicki. 
Washington, and therefore fellow passengers on the subway, passers-by, employees, and customers.

Miłosz's meeting with African Americans took place on several levels: the poet read journalism about the Negro issue, described the situation of black people in the press, was interested in their painting and sculpture - he reviewed the most interesting works, read and translated poems by black poets, devoted some space to them in his own poetry, and finally made the first Polish translation of Negro spirituals. ${ }^{61}$ As a secretary of the Embassy, he visited an African American university where a Chopin concert took place - he mentioned this in a letter to Iwaszkiewicz (Zaraz po wojnie, 250). Of course, not all the activities mentioned here happened at the same time. On the contrary, we can observe a gradual increase in Miłosz's interest in the affairs of African Americans and a growing understanding of the complications of life in a multi-racial society. It should be remembered, however, that the poet then knew more than he let on - his comments on racism were characterized by a selfcensoring reticence. Secondly and no less interestingly, although he devoted more time, and lines of text, to African Americans, his curiosity about them did not last. This was unlike his encounter with Native Americans, whom the diplomat neither saw every day nor described at length, and whose work - apart from what he saw in Taos - was unknown to him. How to explain this exhaustion? It is probably related to his functional, or better yet, metonymic approach to this issue.

Initially, Miłosz revealed the background of someone who was a graduate of a pre-war European gymnasium (high school), who learned about the history of the American Civil War. He jokingly referred to this knowledge in his correspondence, especially at the beginning, when he shared his first impressions of the USA. From the very beginning, he was curious about the black minority taking a specific place in society - he tried to define and explain its various coordinates. It is then that his first comments appeared in the series $\dot{Z} y c i e$ w USA. In the last issue of Odrodzenie of 1946, he described the organization of the Columbians, a successor of the Ku Klux Klan, established in Atlanta. At the beginning of 1947, Miłosz wrote about violations of the electoral rights of black people.

While Miłosz paid attention to glaring examples in the series $\dot{Z} y c i e w U S A$, he was silent on the realities of everyday life: segregation on public transport, and restrictions on African American participation in cultural events. ${ }^{692}$ Only in his discussion of the Writers' Conference at Bread Loaf did he report the story of one of its participants, but he did this for much deeper reasons, and with different intentions:

691 Not many African-American texts were published in Polish literary press. See Lindsay, V.: "Kongo. (Studium szczepów murzyńskich)” [Congo (A Study of Negro Tribes)], Twórczość 1946, issue 7/8, p. 95.

692 He writes more on this in the article "Literatura amerykańska w 1948 roku" [American Literature in 1948]. 
Roger's maladaptation dates back to his school years. "I was in an art school that had three departments: fine arts, music and writing. Many blacks studied at the school and the relations between the whites and the blacks were good," he says. I made a mistake. Once I bought ice cream for twenty Negroes. A whispered rumor went around the school and I had fingers pointed at me: "a rich Jew." A few days later, while playing football, all the blacks ganged up on me. They pretended to be fighting with one another, but I was at the bottom of a big pile of bodies and they beat me till I bled. The whites shunned me because I had given to the blacks. I had to leave the school. But I am stigmatized everywhere: I come from a family that is Jewish and rich - a bad combination, and because of my disability. The worst thing is the awareness of being an outsider. ${ }^{693}$

Miłosz quickly understood the risk of writing about the problems of African Americans - in the atmosphere of growing anti-American propaganda in Poland, his testimonies could be read as echoes of Polish Zoiluses. Therefore, shortly after his reports, he commented on the accusation of racism repeated in Polish press. He dealt with in the seventh issue of Odrodzenie, and the pretext for this was the manipulation in Kuźnica:

In the issue of Kuźnica of December 10, 1946, on the first page, under the great title: "One of the four freedoms: freedom from fear" there are photographs of Ku Klux Klan members and hanged Negroes.

It is puzzling that a magazine of left-wing intellectuals uses sensationalist methods, which in America are the monopoly of a certain type of daily press, far from intellectualism, avoided with contempt by educated people. Presenting America as a country where Negroes are hanged is more or less as precise as writing about Poland that everyone there wears bowler hats, because this is the type of hat traditionally worn by owners of horse-drawn carriages in Krakow. The black issue in the United States of course does exist, but it is discussed and written about openly here. Nowhere in the world have so many books been written on this subject. To those who are interested, one may recommend Myrdal's monumental study An American Dilemma. A large number of organizations, publishers, educational films, and churches fight against racial discrimination - and the progress achieved so far is unquestionable. ${ }^{694}$

Miłosz added an explanatory note to his previous comments. In it, he pointed out that racial differences clearly translated themselves into class divisions and determined one's place in the social hierarchy. If at all possible, the advancement of non-white citizens required more time and effort. He pointed out that the status of black people did not differ significantly from the status of immigrants from Central and Eastern Europe, but the latter were more efficient in climbing the American social ladder. Because of their low salaries, African Americans and Poles were unexpectedly often - as he wrote - neighbors in the poorest districts of big cities, so when it came to antagonism between whites and blacks, there were a fair number of disputes between these two groups. He did not hide the fact that "the standard of living of the black population, very low for American conditions, was nonetheless probably higher than

693 Miłosz, Czesław: "Zabawy i spory” [Games and Arguments], Odrodzenie 1947, issue 44, p. 4.

694 Nowak, J. M. [Miłosz, Czesław]: Życie w USA, Odrodzenie 1947, issue 7, p. 9. 
the standard of living of people in Poland." ${ }^{695}$ The correspondent also touched on the mechanism of social regulation in America - while enjoying the rights of democracy, people were not free from economic fears and it was their financial stability that determined the comfort of their lives. In a similar tone, he said in the reports for the Ministry of Foreign Affairs: "These symptoms [of racism - E.K.] are not as glaring as a European is used to imagining them and I think that they often obscure more important issues (...)." 696

Since this polemic with Kuźnica in 1947, the author of Życie w USA made no further comments in the press on the situation of African Americans until 1950, when he compared the situation of Polish economic emigrants and the black population in the United States:

\begin{abstract}
The particular racism that occurs in treating people of Slavic origin is simply the result of class habits - just as this is exhibited more strongly in relation to Negroes, after all the point is nothing else than forcing the Negroes to 'know their place,' i.e. the place of a person used for menial work. (...)

The history of Polish economic emigration in America will be discussed, I believe, at great length both in Poland and in the United States. For someone who knows America, it is clear that it is connected with the victory of progressive forces in America, because only the abolition of the "origin-based" segregation will heal American Poles of their inferiority complex and make them proud of their tradition. Let us take into account that whoever wants to find an unbiased picture of the history of the Negroes in America today has to draw on the works of Marxist historians. The same will apply to other population groups, whose role in the development of America is now subtly diminished. ${ }^{697}$
\end{abstract}

In the essay entitled "Obyczaje” [Customs], written in 1950, Miłosz added nuance to his earlier statements about the situation of African Americans, drawing attention to relations within this group:

Before entering the theatre there were picketers. People steaming with moisture, mostly Negroes, carrying signs saying: "This theater is racist," "Down with Hitlerism," "Fight against racism." The reason for this was that the theater did not sell tickets to Negroes and only allowed whites. (...)

As we know, American blacks are descendants of slaves, caught in different parts of Africa, and therefore coming from different tribes and nations, so there are different anthropological types and different shades of skin: from almost completely white to ebony black. Addition of white blood has enlarged these differences. At a large university I know, students with light

695 Ibidem, p. 9.

696 Raport sytuacyjny o nastrojach na terenie działalności Konsulatu Generalnego w New Yorku za okres 1 VIII - 1 IX 1946 [Situational Report on the Moods in the Area of Operations of the New York Consulate for the Period from Aug. 1 to Sept 1, 1946]. AMSZ, c. 21, b. 87, f. 1182.

697 Miłosz, Czesław: "Poeta-pieśniarz" [Poet-Bard], op. cit., pp. 5-6. This issue is nonetheless a permanent feature on the reports written for the Ministry of Foreign Affairs. 
skin and straight hair belong to some fraternities and sororities, and those with dark skin and curly hair belong to other "inferior" ones. (...) These differences are by no means detached from economic conditions. But these are very complicated issues, dating back to the times of slavery. There are sharp conflicts among the Negroes, and contempt for the "blacks." Their financial and cultural elites like to derive their origins from the manor house service, as opposed to the "black" descendants of slaves working on plantations. The people employed in the house service often had European features (selected by the owners) and light-colored skin (sexual relations between the owners and the service). Standing at a much higher cultural level than the workers on the plantation, they had a better start when slavery was abolished. This scheme, however, does not exhaust the sociological complexities, including the problem of "borderline" Negroes, completely white, including: "Should I cross over to the other side?"698

Miłosz's decision against taking up the issue of racism very often does not allow us today to assess what, apart from his personal experience, was the source of his knowledge about racial discrimination. We do not know if any books, apart from An American Dilemma by Gunnar Myrdal and The Negro W. E. B. Du Bois, ${ }^{699}$ shaped his awareness of these issues. The 1940s, after a fertile period of two decades, were still abundant in valuable works on racial relations. Among them, to name but a few in chronological order, there were books by the recent precursors of the Harlem Renaissance: The Negro in Art by Alaine Locke, ${ }^{700}$ Dusk of Dawn by W. E. B. Du Bois, ${ }^{701}$ American Negroes and the War by Earl Brown, ${ }^{702}$ Modern Negro Art by James A. Porter, ${ }^{703}$ Black Metropolis: A Study of Negro Life in a

698 Miłosz, Czesław: "Obyczaje” [Customs], op. cit., p. 77 and 87.

699 Miłosz took an excerpt out of the book by Du Bois (published in New York by Henry Holt and Co. in 1915). See Beinecke Library, Box 121, Folder 1868.

700 Alaine Locke's album The Negro in Art. A Pictorial Record of the Negro Artist and of the Negro Theme in Art (first printing, Washington D.C., 1940) presented the history of emancipation of the black artist, the evolution of the subject of the Negro in the visual arts, and African sources of black art in the United States.

701 The autobiographical essay by Du Bois (first edition: New York, Hartourt, Brace\&World Inc., 1940), is among others a reflection on the history of race as an arbitrary concept built by white English-speaking people. Du Bois overthrows its pseudo-scientific premises, revealing its ideological background. He analyzes the model of democracy based on Christian morality and the rules of white domination. He discusses the conditions in which African Americans as a minority may transform from a group of consumers into important political and social subjects - the background for these considerations is also Marxism. Du Bois considers the time after the end of World War Two as the most suitable time for conducting a revolution aimed at achieving equal rights for African Americans. 702 Earl Brown's article (first published in Harper's Magazine, April 1942) described the rules of racist segregation in the US Army and glaring examples of discrimination of blacks by white soldiers. 703 This book by Porter (first edition: New York, Dryden Press, 1943) is a comprehensive presentation of the history of African American art and craft of from the times of slavery, through the Civil War, until the 20th century. It describes the emancipation of black artists, the process of their individualization and achievement of their own identity, including the New Negro Movement, as well as the relations between African American art and mainstream American art, achievements in painting, sculpture, graphics and popular culture of the black minority. 
Northern City by St. Claire Drake and Horace R. Cayton, ${ }^{704}$ A Rising Wind by Walter White, ${ }^{705}$ and Color and Democracy by W. E. B. Du Bois. ${ }^{706}$ It is safer to assume that Miłosz, a reader of the literary press, was familiar with the contours of the discussion on African Americans at the time. It was not without good reason that Jerzy Giedroyc in the 1950s recommended to him to continue reading American books. ${ }^{707}$

In parallel to his interest in the social and economic situation of African Americans, a fascination with specific, albeit anonymous people manifested itself as well. Miłosz saw them on the New York subway and noted down his observations. His works include several such detailed portraits - he preserved them in his "Notatnik amerykański" [The American Notebook]. At that time, people to him are human stories. Even though he renounces simple relationships with photography, and he does not believe that the relationship with objects can be improved at the price of renouncing the feelings, experiences, and thoughts of the portraitist, one may ask whether his pictures were not inspired by Walker Evans' famous photographs. It was said of Evans that he used the camera as a typewriter, that he was a writer, rather than a photographer, ${ }^{708}$ and his works were called photo-essays. Miłosz's literary pictures seem to have a similar status, which used the New York subway, the suburban railway, and the train for their background. Only a few such miniatures are preserved in Kontynenty:

704 The work by Drake and Cayton, Black Metropolis, (first edition New York: Harcourt, Brace \& Co., 1945), was an eminent pioneering sociological study devoted to black residents of Chicago in the first half of the 20th century. It described the evolution, socioeconomic and political emancipation, and changing customs of this group from the moment of their settlement, in relation to the urban transformations that took place in their neighborhood under the influence of these changes.

705 The essay by Walter White (published in Garden City, New York by Doubleday, Doran and Company in 1945) concerned discrimination against black war veterans, and their status in relation to people of color in the other countries the Allies fought for, as well as the future of international policy based on racist principles. White concluded, "See what the United States does to its own colored people; this is the way you colored people of the world will be treated if the Allied nations win the war!" (A Rising Wind, op. cit., p. 154). He went on to ask, "Can the United States, Britain, and other "white" nations any longer afford, in enlightened self-interest, racial superiority?" (Ibidem, p. 154).

706 The book by Du Bois Color and Democracy: Peace and Colonies (first edition: New York, Harcourt, Brace \& Co., 1945) takes up the issues of globalization, post-war democracy and possibilities of introducing it in the countries ruled by colonial powers, the future of the colonies, and the difficult situation of their inhabitants, economic policies based on exploitation of the colonies, the significance of Russia and its ideology in the modern world, the mission of world organizations and the international community in settling armed conflicts and their actions for peace.

707 In the essay "Valka, ou hors de temps" from 1955 (Beinecke Library, Box 127, Folder 2038) Miłosz recalls his several-day stay in Germany. The essay starts with a recollection of his reading of Uncle Tom's Cabin and touches on the issue of discrimination against blacks, who are referred to with the French term 'Negres.' Miłosz compares the phenomenon of slavery in the United States with forced labor in Germany during World War Two.

708 Evans collaborated with the weekly Time that Miłosz read when preparing his official reports. 
An old Negro, with whom I had an argument the previous day, came up to me in the morning and said, "I'm sorry." I asked him why he did this, and whether it was worth remembering such small details. With a cautious movement of his hand, he let me know that there were powers lurking in the air, ready for anger. "You are too young. When it starts, it's small. Then stop it. You will forget, you will let it grow, it will become big, and then it will be too late." He stood in front of me, wearing a blue shirt, with the sleeves rolled up, veins bulging on his hands. His face emerged from the chaos of known shapes and colors, and he was an envoy, and the mysterious smile of a good man meant: "Is it not so? Was I not rightly told at night to warn you?" I saw bloody decks of ships, metal shackles digging into dark skin, and his ancestor, with the same smile, summoning spells of magical leopards that fell down beside him, like pears from an invisible tree. An hour later I tore up a letter, and in this way a matter between me and a certain young girl was finished (Kontynenty, 281).

The scene from the composition "Spotkanie" [Encounter] is a synthesis of Miłosz's earlier intuitions. From his scattered writings of the 1940s, this an image of a black American emerges: someone authentic, straightforward, internally free, with strong religious intuitions. One may guess the reasons why the poet observes him so intensely. A descendant of slaves, bearing the historical burden of injustice and the social stigma of a misfit, draws his attention when he manifests his dignity and biblical piety. This piety, growing out of a strong faith in God's providential power, manifesting in respect for God's affairs and his own humanity, touches the poet's most intimate dilemmas. Alongside Native Americans and Mexicans, Miłosz considers African Americans to be the only living people in America. He discovers in the black artist, in the anonymous, accidental passer-by, and in himself, a common trait that allows him to build a different minority, a different community. It is not only their common alienation, deeper than the racial and ethnic condition of exiles, and perhaps - in the figurative sense of the word - slaves. Initially, the poet only sensed this, and later he wrote about it in his letters and articles. In the article "Abstrakcja i poszukiwania" [Abstraction and Searching], he compared Peggy Guggenheim's collection with an exhibition of works by black sculptors and painters. Miłosz consistently upheld his view that, following European surrealism and abstractionism as if the war had never taken place, the mentees of Peggy Guggenheim risked academism. The artists who glanced surreptitiously at the Old World, for fear of rejection, suppressed their own imagination, which turned their art sterile. Black artists, who showed a freer attitude toward the past or, as it were in an act of protest, distanced themselves from white art, whether American or European, sometimes achieved greater independence and originality. The poet was interested here in the combination of three elements: the knowledge of and creative reference to the Western tradition, fidelity to one's own history, understood as a community experience and a personal experience, as well as the sense of sacrum, with a biblical basis, which organized the two previous elements as the superior principle. This was soon to be one of Miłosz's own points of access, and because of this, it is necessary to take into account his inspirations from black art in his own artistic search. He described an exhibition of African American works not 
only in relation to the collection of Peggy Guggenheim. He used it as an emblem of his own views in the national discussion on realism, and the tasks and future of art: ${ }^{709}$

One may also set the following requirements: 1 ) that the artist may present only some things (the subject matter); 2) that they should be "lifelike" in the sense that everyone will point their fingers and say: "Oh! a house. Oh, a general!"; 3) and presented in such a way as to awaken in the greatest possible number of viewers certain feelings and passions, considered beneficial in advance. However, such rules have little in common with considerations about art. This is a sphere of orders and prohibitions, and it is also a matter of ensuring the means that are adequate to effectively force the artists to obey. Of the historical figures who tried to do so, we have made the closest relative acquaintance of Hitler. What theory is attached to such requirements unrealistic or realistic - is in fact irrelevant. ${ }^{710}$

The author certainly understood how courageous these words were. If one disregards the immediate political context of these comments, another thing is striking - the continuity Miłosz's imagination and the stability of his beliefs.

In the painting and sculpture of African Americans, in Negro spirituals and in poems of black poets Miłosz discovered the direction in which his own thought was heading. It moved between politics and metaphysics, between history and theology. A synthesis of this practice could be found in the Negro spirituals he translated. He prepared Polish versions of a total of fourteen songs, five of which appeared in Polish press in the 1940s: four in Nowiny Literackie ${ }^{711}$ and then one at the Odrodzenie. ${ }^{712}$

709 In the article, Miłosz passes over the issue of realism represented in American painting both by white artists (George Bellows, Georgia O’Keeffe, Charles Scheeler, Edward Hopper, Grant Wood, Raphael Soyer, Philip Evergood, Ben Shahn), and black ones (Norman Lewis, Charles Wilbert White, Hughie Lee-Smith, Romare Bearden). It does not seem that passing over this issue resulted from ignorance. The poet regularly visited museums and art galleries in New York and Washington, hence it is not likely that he did not come in contact with the works of artists who were already well-known at the time. Neither did he mention the American version of Socialist realism. Either the author wanted to build a clear antinomy that would help him formulate his own position in the Polish discussion on realism, or he did not want to mix various realisms stemming from different intellectual traditions. Perhaps he also wanted both at the same time. The differentiation of realism in 20th century world painting is interestingly discussed by Brendan Prendeville in Realism in 20the Century Painting, New York: Thames\&Hudson world of art, 2000.

710 Miłosz, Czesław: "Abstrakcja i poszukiwania" [Abstraction and Searching], op. cit., p. 3.

711 Nowiny Literackie of 1948, issue 24, p. 4 published the songs works "Zejdź Mojżeszu" [Go Down Moses], "Kiedy złote trąby zagrają" (probably a free translation of "Where Shall I Be When the First Trumpet Sounds"), "Widzę księżyc wschodzi” [I Know Moon-rise], and "O, chciałbym mieć orle skrzydła” [I Wish I Had an Eagle’s Wings].

712 The song "Jerycho"[Jericho] was published in Odrodzenie 1948, issue 12, p. 4. In Kontynenty, Mowa wiazana [Fettered Speech, Oratio Vincta] and Przektady poetyckie [Poetry Translations], the collection of translations of Negro spirituals (with the exception of the song "Zejdź Mojżeszu" [Go Down Moses]) was published in the following order: "Bóg będzie ogniem spalać ten świat” [God's Gonna set this world on fire], “O, chciałbym mieć orle skrzydła” [I Wish I Had an Eagle’s Wings] "Jerycho" [Jericho], "Mój wojenny strój tutaj złożę" [Going to Pull my War-Clothes], "To ja, o Panie" 
All of Miłosz's translations were placed in an anthology submitted for publication, which never appeared as a separate book - nine songs were published in Kontynenty and Mowa wiazana [Fettered Speech, Oratio Vincta], which were then reprinted in the volume Przekłady poetyckie. As can be seen, the translator decided against publishing the Negro spirituals "My Blood Ran Icy-Cold," "Good News," "The Chariot's Coming” and "Singing' Wid a Sword in My Han'," whose manuscripts he included in the so-called "Black File." The publication of Negro spirituals was also the subject of spirited correspondence.

Apart from the fact that the translations of Negro spirituals were not placed in a propaganda context, Miłosz's other requests were not followed. The poet complained about this in a letter to Ryszard Matuszewski, who explained to him that Negro spirituals were not being received with enthusiasm:

Recently I was angry with Nowiny Literackie for killing my Negro spirituals by printing a large introduction and only two or three tiny poems. Perhaps these spirituals are not as gripping, as you say, in Polish, but a larger portion of them gives an idea of the aura that gave birth to them, and that is what I wanted to achieve. I made these translations as lyrics to music, and they should be treated as such (Zaraz po wojnie, 445).

Miłosz provided his translations with a commentary, which was a synthesis of James Weldon Johnson's and Carl Sandburg's works.

Four of the ten translations were selected for publication, and the first one to be included was "Go Down Moses." Were the intentions of the editorial office consistent with Miłosz's plan? When asked about the translator's political calculations, we may find several answers that are not mutually exclusive. Although Miłosz did not reveal it in his letters - just as in the case of "Małe wypisy historyczne" - he may have written in Aesopian language, using someone else's voice to comment on the current Polish reality. The commentary to the song does not overlook the fact that Negro spirituals united slaves in underground activities, the point of which was not the Kingdom of God... Miłosz perversely seems to provide succor to propagandists in Poland, who exploited the subject of slavery and racism in the USA. Touching on the affairs of the people, and popularizing their work, he additionally pushes the accusation of diversion away from himself. And only the translator knows that he took the Negro spirituals out of the political framework in which they were originally put by their well-known collector and researcher, James Weldon Johnson. In the book

[It’s me, Oh Lord!], “Niczyjej tutaj modlitwy nie słyszę" [I Couldn’t Hear Nobody Pray], "Kiedy złote trąby zagrają" [probably a free translation of "Where Shall I Be When the First Trumpet Sounds"], "Widzę, księżyc wschodzi” [I Know Moon-rise], and "Czasem ja jestem” [no single original; the first four lines come from a rare version of the spiritual "Sometimes I Feel Like a Motherless Child," while the four lines following the page break are the beginning of "You May Bury Me in de East."] (cf. Jakubiak, Katarzyna 2011). 
Negro Americans, What Now? Johnson shares the belief that there is no problem of black discrimination in Soviet Russia, and speculates on the role of communism in combating racial prejudice:

\begin{abstract}
Those who hold this faith point to Soviet Russia as a land in which there is absolutely no prejudice against Negroes. This is unquestionable fact, but I can see no grounds on which to attribute it to communism. There was no prejudice against Negroes in Tsarist Russia. Tsarist Russia was the country that could honor a black Hannibal; the country that could make a mulatto Pushkin its national poet; the country in which university students of St. Petersburg could unhitch the horses from the carriage of Ira Aldridge, the black American tragedian, after his performance of Othello, and themselves draw him back to his hotel. The simple truth is: the Russian people have no prejudice against Negroes. (...)

It may be argued that although there is not and has not been any anti-Negro feeling in Russia, it is the country in which anti-Semitism was stronger than in any other; and that oppression and repression of the Jews have been greatly abated or entirely wiped out by Communism. Such an argument goes to prove the possibility that Communism in the United States would wipe out oppression and repression of Negro Americans and give them a status of equality. ${ }^{713}$
\end{abstract}

Johnson's works - apart from the intention of consolidating the oral tradition of African American culture - had a political goal, if only reduced to a minimum: to appear in the space of culture, in the media, and to provoke discussion. Miłosz made the opposite gesture: firstly, by gathering the sources of for his translations, he showed that black people in America enjoyed freedom of speech, had access to the media, and developed and cultivated their heritage; secondly, he used the voice of former slaves - as they themselves used religious songs - as a political voice to the second power. But, according to his auto-commentary, in the Negro spirituals, he was more attracted by the word interwoven with the Logos, by mediation between man and God. On a deeper level, more important for Miłosz, these songs tell the story of an exile in the broadest and at the same time most elementary sense. Even then, they are for him an achievement of a certain poetic ideal: they tell as much a concrete story of a community, as that of man in relation to himself, the world, and God. Are there no such ambitions - regardless of whether they are fulfilled or interpreted in this way in Traktat moralny [Treatise on Morals]?

In the end, and for the poet this was not an inconsequential matter, Negro spirituals were a manifestation of unrestricted creativity, free from literary fashions and programs. This creativity grew out of the most intimate and authentic sources, effectively resisting any classification. In several places, Miłosz confessed to working on his own collection of poetry of various nations, in which the so-called African Anthology was to take an important place. ${ }^{714}$ Translation of Negro spirituals was

713 Johnson, James Weldon: Negro Americans, what now?, New York: The Viking Press, 1934, pp. 8-10.

714 In the archival group of Miłosz's Translations kept at the Polish National Library, there are the 
interesting for Miłosz - apart from the above considerations - as a challenge for his mastery of the Polish language, and a lesson in style. The reader of Whitman and Sandburg appreciated the beauty of phrasing, which imitated biblical verse, the incantational qualities, non-trivial parallelisms, rhythmic contrasts between the chorus sections and the verses constructing the story, expressing the spirit of the psalms of David. Did the Negro spirituals influence the translator's own poetry? Yes, although Miłosz obliterated the traces of these influences. An example would be the "Pieśń murzyńska” [Negro Song]:

Red river Perry

Red river Perry

The Moon rises over the water

The Moon rises over the water

Cotton dust falling dust on the leaves of acacia trees mocking

bird hot dusk day and night no respite for us.

Red river Perry

I dreamed that I had wings like an eagle

And I rose into the blue

I dreamed I spread my wings

And I soared over the great plain

The Moon rises over the water

Tree of whisper tree of sorrow in the dust of twilight in the snare of roads

in the dust of cotton tree of terror

And I shook off my heavy burden

And I heard the trumpet call

And I stepped with motionless feet

Onto the golden ladder of clouds

Stars of the heavens welcomed me

Red river Perry

Red river Perry

The Moon rises over the water

The Moon rises over the water ${ }^{715}$

poems "Decision" by Owen Dodson, "Megalu" by Helene Johnson, "Return" by Hugh Doston Carberry, “I Don’t Know why you Think, Soldier” by Nicolás Guillén, published in the 1940s in Odrodzenie. In the planned anthology of translations, they were included in the part of South American Poets.

715 Miłosz, Czesław: "Pieśń murzyńska” [Negro Song], Odrodzenie 1948, issue 8. 
Would it be possible to trace other traces of Miłosz's interest in Negro spirituals, ones that were hidden even deeper? Perhaps it would, if one were to reach into his biography, or compare them more carefully with his work of that time. It is not difficult to reveal the space of dialogue between the poetry and translations of the author of Daylight. In the midst of his translations of Negro spirituals and his poems, pairs of works are created spontaneously - for example, "Na śpiew ptaka nad brzegami Potomaku" [On a Bird's Song Heard on the Banks of the Potomac] and "Going to Pull My War-Clothes," “Grób matki”[Mother's Grave] and "It's Me, O Lord,” "Jericho” and "Który skrzywdziłeś” [You Who Wronged].

After the publication in Nowiny Literackie, it was the song "Jericho" that Miłosz decided to include in the group of translations under the title „Lud będzie żył. (Przekłady z poezji amerykańskiej)” [The People Will Live On. (Translations from American Poetry)], which was published in Odrodzenie. It is not known whether the title came from Miłosz or from the editorial office, but the poet himself added the following comment to the set:

The poems that I am providing in translation have been selected, as is easy to see, according to a certain rule. I wanted to include popular works that were similar in character to folk poetry. Thus, the issue of the date of their creation was therefore left in the background.

"Jericho" is one of the most famous Negro spirituals. These anonymous black songs were only recorded after the Civil War. Since there is no equivalent of the dialect of American Negroes in Poland, I translated them into ordinary literary language. Walt Whitman's poems (1819-1892) exerted, even if not directly, a great influence on the development of Polish poetry. Collecting translations penned by various poets, would be a rewarding task for a discerning publisher. Edwin Markham (1852-1940) wrote the astonishing poem "The Man with a Hoe" in 1899 under the influence of Millet's painting. This poem was translated into almost all languages of the world. Vachel Lindsay (1879-1931), a poet-reciter, using what we could describe as tawdry county-fair motifs in his poetry, in the poem "Simon Legree," speaks in the language of the imagination of Negro slaves. Carl Sandburg (b. 1878) is considered the continuator and successor of Whitman. The poem "Lud będzie żył" [The People Will Live On] closes the last volume of Sandburg's poem "The People, Yes" dedicated to his "contributors dead and living." "16

Miłosz decided against using the criterion of race in his selection of translations. In this group he juxtaposed Whitman, Markham and poets of the Chicago school from the turn of the 20th century with an anonymous Negro spiritual. Despite his declarations, the common denominator of the works seems to be the problem of evil, under such names that absorbed the poet the most in the 1940s, and specifically religious, moral interpretations of social evil. The small collection of poems shows how persistently

716 Miłosz, Czesław: “Lud będzie żył. (Przekłady z poezji amerykańskiej)” [The People Will Live On (Translations from American Poetry)], Odrodzenie 1948, issue 12, p. 4. 
and consistently the author of Rescue searched in foreign poetry for what already attracted him in the pre-war years.

Now, additionally, he used translation of engaged art with a deeply moralistic basis, in the function of his own voice, for saying things he himself could not utter more strongly. It is difficult to overlook the common tone of this poetic statement somewhat like Lindsay, whom he translated, through these poems, Miłosz delivers a message of strength and hope, a prophetic speech, taking the office of a teacher, guardian, and defender. Loading political gunpowder into the cannon of propaganda, he engages in a risky game that is least concerned with building a racially and ethnically diverse landscape of contemporary American poetry. Miłosz's functional, metonymic treatment of the Negro issue in the 1940s would thus consist in using it as a costume, helpful in taking a stance in the political and artistic discussions in Poland. However, it would be a simplification to say that this is the poet's only motivation, or at least the main one, in presenting the work of black poets. That this was not the case can be inferred on the basis of the translations published in Odrodzenie in 1949, in the small collection być „Przekłady z poezji murzyńskiej” [Translations from Negro poetry]. ${ }^{717}$ Again, it is not known who suggested the common title, in this case perhaps the most misleading, since the group of eight works included poems by black American female poets, as well as authors from Jamaica, Haiti, and Puerto Rico. ${ }^{718}$ Even if the racial criterion indicated here were sufficient for such a grouping of the works, it fails in the case of artists from such diverse ethnic and cultural backgrounds. The basis for this juxtaposition was either an accident - Miłosz added no commentary to it - or the value of their thematic and aesthetic diversity. Four of the poems, by Margaret Walker, Helene Johnson, Luis Palés Matos, and Jacques Roumain, presented a black hero, bore the signs of engaged poetry, and had a more or less exposed metaphysical or religious frame. The poem by Bruce McM. Wright touched on the experience of war, while the works by George Campbell and H.D. Carberry showed almost no interest in current historical or social issues. Such a selection of authors and poems illustrated Miłosz's interests at the time, and simultaneously showed that his reading choices were not politically conditioned. What is more, the poet's intentions transcended mere popularization: one may speculate to what extent the poem of the excellent Jamaican poet reminded him of his last poem from the cycle The World. (A Naïve Poem) and to what extent it influenced the choice of title for the volume from 1953.

717 Miłosz, Czesław: “Przekłady z poezji murzyńskiej” [Translations from Negro Poetry], Odrodzenie 1949, issue 20, p. 8 .

718 Juxtaposing the translations of the above authors is a gesture which predated thinking in terms of the Black Atlantic by far. On this, see Gilroy, Paul: The Black Atlantic: Modernity and Double Consciousness, Cambridge: Harvard University Press, 1993. 
The road, whose culmination is Miłosz's inspiration in the work of poets of many races and languages, also includes emancipation of the African-American issue in his imagination and work during his first stay in the United States. 